\title{
Perceptual Stimulation Group Activity Therapy on Hallucination Patients at the Pemenang Jiwa Sumatra Foundation.
}

\author{
J Alex Tumanggor ${ }^{1}$, Bika Utami², May Thent G Daeli ${ }^{3}$, Winda V Purba ${ }^{4}$, \\ Yolanda V Silaban ${ }^{5}$, Yosi Meichi Sianturi6 \\ widayanasilaban@gmail.com
}

\begin{abstract}
Hallucinations are when a person experiences a change in the pattern and amount of stimulation that is initiated internally or externally in the vicinity with a reduction, exaggeration, distortion, or abnormality in response to each stimulus. Management of schizophrenic patients includes group nursing actions, such as group activity therapy. Group activity therapy is a psychotherapy performed by a group of patients together by way of discussions with each other led or directed by a trained therapist or mental health worker. The number of patients who participated in the perceptual stimulation group activity therapy amounted to 6 people. As a result of this therapy, after receiving perceptual stimulation group activity therapy, patients at the Pemenang Jiwa Sumatra Foundation increased their knowledge, understanding of how to control hallucinations and knowing how to have done it. Increased knowledge shows that patients are able to remember sp 1 - 4 from group therapy activities. It is recommended that patients who experience hallucination problems can be given Group Activity Therapy so that patients are able to perform actions independently and be able to cooperate with other patients.
\end{abstract}




\section{BAB 1 \\ PENDAHULUAN}

\subsection{Latar Belakang}

Gangguan Jiwa merupakan salah satu dari masalah kesehatan terbesar selain penyakit degenerative, kanker dan kecelakaan. Gangguan jiwa juga merupakan masalah kesehatan yang serius karena jumlahnya yang terus mengalami peningkatan. (Nasriati, 2017). Jumlah penderita gangguan jiwa di dunia adalah sekitar 450 juta jiwa termasuk skizofrenia (WHO, 2017).Kondisi untuk Asia Tenggara tidak berbeda dengan kondisi global dimana dilihat dari YLDs contributor lebih besar pada gangguan mental $(13,5 \%)$.

Kasus gangguan jiwa di Indonesia berdasarkan hasil Riset Kesehatan Dasar Riskesdas tahun 2018 meningkat. Peningkatan ini terlihat dari kenaikan prevalensi rumah tangga yang memiliki ODGJ di Indonesia. Ada peningkatan jumlah menjadi 7 permil rumah tangga. Artinya per 1000 rumah tangga terdapat 7 rumah tangga dengan ODGJ, sehingga jumlahnya diperkirakan sekitar 450 ribu ODGJ berat. Prevalensi (per mil) Rumah Tangga dengan ART (Anggota Rumah Tangga) Gangguan Jiwa Skizofrenia/Psikosi suntuk Sumatera Utara sebesar 6,3\% (Riskesdas, 2018). Gangguan jiwa berat termasuk skizofrenia yang bersifat kronis yang ditandai dengan gangguan komunikasi, gangguan realitas (halusinasi atau waham), afek tidak wajar atau tumpul, gangguan fungsi kognitif serta mengalami kesulitan dalam melakukan aktifitas sehari-hari (Pardede \& Hasibuan, 2019)

Skizofrenia merupakan kondisi psikotik yang berpengaruh terhadap area fungsi individu, termasuk berpikir, berkomunikasi, menerima, menafsirkan kenyatan, merasakan dan menunjukkan emosi serta penyakit kronis yang ditandai dengan pikiran kacau, delusi, halusinasi, dan perilaku aneh. Pasien skizofrenia sering mengalami halusinasi. Faktor-faktor yang mampu 
mempengaruhi kekambuhan penderita skizofrenia dengan halusinasi meliputi ekspresi emosi keluarga yang tinggi, pengetahuan keluarga yang kurang, ketersediaan pelayanan kesehatan, penghasilan keluarga dan kepatuhan minum obat pasien skizofrenia (Pardede, 2020).

Dampak yang dapat ditimbulkan oleh pasien yang mengalami halusinasi adalah kehilangan control dirinya. Dimana pasien mengalami panic dan perilakunya dikendalikan oleh halusinasinya (Samal, Ahmad \& Saidah, 2018). Faktor-faktor yang mampu mempengaruhi kekambuhan penderita skizofrenia dengan halusinasi meliputi ekspresi emosi keluarga yang tinggi, pengetahuan keluarga yang kurang, ketersediaan pelayanan kesehatan, penghasilan keluarga dan kepatuhan minum obat pasien Skizofrenia (Pardede \& Laia, 2020).

Penatalaksanaan Pasien skizofrenia yang mengalami halusinasi adalah dengan pemberian obat-obatan dan tindakan lainnya seperti terapi kejang listrik dan terapi aktivitas kelompok. Terapi aktivitas kelompok merupakan suatu psikoterapi yang dilakukan sekelompok pasien bersama - sama dengan jalan berdiskusisatusama lain yang dipimpin atau diarahkan oleh seorang Therapist atau petugas kesehatan jiwa yang telah terlatih. Keuntungan dalam terapi aktivitas kelompok yaitu dapat mengobati Pasien dalam jumlah banyak, anggota kelompok dapat mendiskusikan masalah masalah mereka, sehingga menurunkan perasaan terisolasi, perbedaan perbedaan, dan meningkatkan Pasien untuk berpartisipasi dan bertukar pikiran, masalah dengan orang lain, memberikan kesempatan kepada Pasien untuk menggali gaya - gaya berkomunikasi dari Pasien dalam lingkungan yang aman dan mampu menerima umpan balik dari orang lain, anggota kelompok dapat belajar bermacam cara dalam memecahkan masalah, serta dapat membantu memecahkan masalah orang lain (Putri, 2017). 
Terapi aktivitas kelompok merupakan salah satu terapi modalitas yang dapat membantu membangun hubungan dengan orang lain, dengan terapi aktifitas kelompok , pasien dapat bersosialisasi, mengetahui koteks realitas, menyalurkan energi, meningkatkan harga diri (Pardede \& Ramadia, 2021) Tujuan terapi aktivitas kelompok untuk meningkatkan kemampuan sensorik, upaya memfokuskan perhatian, kebugaran jasmani dan mengungkapkan perasaan (Pardede, 2020).

Terapi aktivitas kelompok dilakukan perawat kepada sekelompok pasien yang mempunyai masalah keperawatan yang sama. Terapi aktivitas kelompok seringdigunakan dalam praktik kesehatan jiwa, bahkan saat ini terapi aktivitas kelompok merupakan hal yang pentingdari keterampilan terapeutik dalam keperawatan. Terapi Aktifitas Kelompok (TAK) stimulasipersepsi adalah terapi yang menggunakan aktifitas mempersepsikan berbagai stimulus yang terkait denganpengalaman dan atau kehidupan untuk didiskusikan dalam kelompok. Hasil diskusi kelompok dapat berupakesepakatan persepsi atau alternatif penyelesaian masalah (Rohmani, Lestari \& Kismiyati, 2020).

Manfaat Penggunaan terapi aktivitas kelompok dalam praktik keperawatan jiwa memberikan dampak postif dalam upaya pencegahan, pengobatan atau terapi serta pemulihan kesehatan jiwa. Selain itu, dinamika kelompok tersebut membantu pasien meningkatkan perilaku adaptif dan mengurangi perilaku maladaptive (Andri, Febriawati, Panzilion, Sari,, \& Utama, 2019). Terapi aktivitas kelompok sering digunakan untuk terapi tambahan pada pasien gangguan jiwa. Terapi aktivitas kelompok adalah terapi manual rekreasi dan teknik kreatif untuk memfasilitasi pengalaman seseorang serta meningkatkan respon sosial dan harga diri. Aktivitas yang digunakan sebagai terapi di dalam kelompok yaitu bercerita, mendengarkan musik dan bermain dalam kelompok .TAK sitmulasi persepsi dilaksanakan dengan melatih Pasien mempersepsikan stimulus yang disediakan atau stimulus yang pernah dialami. Kemampuan persepsi Pasien dievluasi dan 
ditingkatkan pada tiap sesi. Dengan proses ini, diharapkan respon Pasien terhadap berbagai stimulus dalam kehidupan menjadi adaptif. Tahap berikutnya adalah mengobservasi reaksi sensoris Pasien terhadap stimulus yang disediakan, berupa ekspresi perasaan secara non verbal (ekspresi wajah, gerakan tubuh).(Maulana, Hernawaty, \& Shalahuddin, 2021).

Berdasarkan survey yang dilakukan di yayasanpemenangjiwa, didapatkan jumlah pasien sebesar 70 pasien, dimana pasien dengan diagnosa halusinasi menjadi diagnosa mayoritas di yayasan pemenang jiwa. Jadi, kelompok tertarik mengangkat diagnosa halusinasi untuk dijadikan terapi aktivitas kelompok sebagai stimulasi persepsi pasien.

\subsection{Tujuan}

\subsubsection{Tujuan Umum}

Setelah mengikuti kegiatan ini Pasien dapat lebih menerapkan stategi pelaksanaan Halusinasi secara fisik dan social dalam mengontrol Halusinasi.

\subsubsection{Tujuan Khusus}

Pasien dapat mengendalikan halusinasi sesuai strategi pelaksanaan (SP)

1. Pasien dapat mengidentifikasi isi, frekuensi, waktu terjadi, situasi pencetus dan respon halusinasi.

2. Pasien dapat mengontrol halusinasi dengan menghardik

3. Pasien dapat mengontrol halusinasi dengan minum obat secara teratur

4. Pasien dapat mengontrol halusinasi dengan bercakap-cakap dengan orang lain

5. Pasien dapat mengontrol halusinasi dengan melakukan kegiatan terjadwal. 


\section{BAB 2 \\ STANDAR PELAKSANAAN TERAPI AKTIVITAS KELOMPOK STIMULASI PERSEPSI PADA PASIEN HALUSINASI}

\subsection{Metode Terapi aktifitas kelompok (TAK)}

Metode yang digunakan pada terapi aktifitas kelompok (TAK) ini adalah metode:

1. Perkenalan diri pada seluruh perawat

2. Menanyakan perasaan Pasien pada saat terapi berjalan

\subsection{Waktu dan Tempat}

Hari/tanggal : 17 Maret 2021

Jam : :10:00 WIB

Tempat : :Ruang PertemuanYayasan Pemenang Jiwa Sumatera

\subsection{Peserta TAK}

Pasien yang mengikuti kegiatan berjumlah 6 orang dari pasien Yayasan Pemenang Jiwa terdiri dari:

1. Tn.E (54th)

2. Ny.N (60 th)

3. Ny. P (35 th)

4. Ny. Y (30 th)

5. Ny. A (39th)

6. Ny.S (54 th)

\subsection{Media dan Alat}

1. Handphone

2. Speaker

3. Music/lagu

4. Buku catatan dan pulpen

5. Jadwal kegiatan pasien

6. Bola 
7. Gambar ekpresi wajah emoji

\subsection{Susunan Pelaksanaan}

Yang bertugas dalam TAK kali ini di sesuaikan dengan petugas setiap sesi yang telah disepakati sebagai berikut :

1. Leader : May Thent Gustavian, S.Kep

2. Co.Leader : Winda Veratami, S.kep

3. Fasilitator 1 : Yosi Meichi Sianturi, S.Kep

4. Fasilitator 2 : Yolanda Vega Widayani S, S.Kep

5. Fasilitator3 : Bika Utami, S.kep

6. Observer 1 : J. Alex Tumanggor, S.Kep

\subsection{Uraian Tugas Pelaksanaan}

1. Leader :

a) Menyampaikan tujuan dan peraturan kegiatan terapi aktivitas kelompok menyiapkan proposal kegiatan TAK

b) Mampu memotivasi anggota untuk aktif dalam kelompok dan memperkenalkan dirinya

c) Mampu memimpin terapi aktivitas kelompok dengan baik dan tertib Menetralisir bila ada masalah yang timbul dalam kelompok

2. Co.Leader :

a) Mendampingi Leader

b) Menjelaskan aturan permaian

c) Menyampaikan informasi dari fasilitator ke leader tentang aktivitas Pasien

d) Mengingatkan leader jika kegiatan menyimpang dari perencanaan yang telah di buat

e) Mengambil alih posisi leader jika leader mengalami blocking dalam proses terapi 
3. Fasilitator :

a) Menyediakan fasilitas selama kegiatan berlangsung Ikut serta dalam kegiatan kelompok

b) Memfasilitasi dan memberikan stimulus dan motivator pada anggota kelompok untuk aktif mengikuti jalannya terapi

4. Observer :

a) Mengobservasi jalannya proses kegitan

b) Mengamati serta mencatat perilaku verbal dan non verbal pasien selama kegiatanberlangsung (dicatat pada format yang tersedia)

c) Mengawasi jalannya aktivitas kelompok dari mulai persiapan, proses , hingga penutupan

d) Memberikan hadiah (reward) bagi pasien yang menang dalam permainan.

\subsection{Kriteria Pasien}

1. Pasien dengan Halusinasi yang sudah kooperatif

2. Pasien yang tidak mengalami gangguan komunikasi verbal

3. Pasien bisa tulis dan baca

4. Pasien yang bersedia mengikuti TAK

\subsection{Antisipasi masalah}

1. Sebelum kegiatan dilaksanakan, perawat memberi kesempatan kepada setiap peserta untuk BAB dan BAK

2. Fasilitator memotivasi peserta yang tidak berpartisipasi

3. Menjaga pintu keluar unuk mengantisipasi Pasien melarikan diri dari tempat kegiatan

\subsection{Langkah-langkah Kegiatan}

\subsubsection{Persiapan}

a) Membuat kontrak dengan anggota kelompok 
b) Mempersiapkan alat dan tempat pertemuaan

\subsubsection{Orientasi}

a) Salam teraupetik

Salam dari leader kepada Pasien. Leader/CoLeader memperkenalkan diri dan tim terapis lainnya.

b) Evaluasi/Vasilidasi

Leader menanyakan perasaan dan keadaan Pasien saat ini.

c) Kontrak

1) Menjelaskan tujuan kegiatan

2) Menjelaskan aturan main yaitu :

a. Berkenalan dengan anggota kelompok

b. Jika ada peserta yang akan meninggalkan kelompok, harus minta izin pada pemimpin TAK

c. Lama Kegiatan 45 menit

d. Setiap pasien mengikuti kegiatan dari awal sampai akhir

\subsubsection{Tahap Kerja}

1. Seluruh Pasien dibuat berbentuk lingkaran

2. Hidupkan music dan edarkan bola berlawanan dengan arah jarum jam

3. Pada saat tape dimatikan, anggota kelompok yang memegang bola, mendapat giliran untuk perkenalan dengan anggota kelompok yang ada di sebelah kanan dengan cara:

a. Memberi salam

b. Menyebutkan nama lengkap, nama panggilan, asal dan hobby.

c. Menanyakan nama lengkap, nama panggilan, asal dan hobby

d. Dimulai oleh terapis sebagai contoh.

e. setelahmemperkenalkandiriPasienmenebakekspresiwajahdanm engambilgulungankertasyang ada di mangkuk yang berisi SP Halusinasi, kemudian pasien diharuskan memperagakan SP yang didapat 
f. Ulangi musik kembali, danPasienkembalimelempar bola, ketika musik berhenti, Pasien yang memegang bola, kembalimemperagakan point $\mathrm{c}$ dan $\mathrm{d}$.

\subsubsection{Tahap Terminasi}

1. Leader atau Co.Leader memberikan pujian atas keberhasilan dan kerjasama kelompok

2. Leader atau Co.Leader menanyakan perasaan Pasien setelah mengikuti kegiatan TAK

3. Fasilitator membagikan Snack

4. Leader atau Co.Leader menganjurkan Pasien untuk sering bersosialisasi, selalubekerjasama, danmemasukkankegiatanmengontrolHalusinasikedalamkegiatanhar iansebanyak $2 \times 1$.

5. Observer mengumumkan pemenang

6. Fasilitator membagikan hadiah kepada pemenang

\subsubsection{Evaluasi}

1. Pasien mengikuti kegiatan dari awal hingga akhir kegiatan

2. Kerja sama Pasien dalam kegiatan

3. Pasien merasa senang selama mengikuti kegiatan 


\subsection{Setting tempat}

1. Terapis dan Pasien duduk bersama dalam lingkaran

2. Ruangan yang nyaman dan tenang

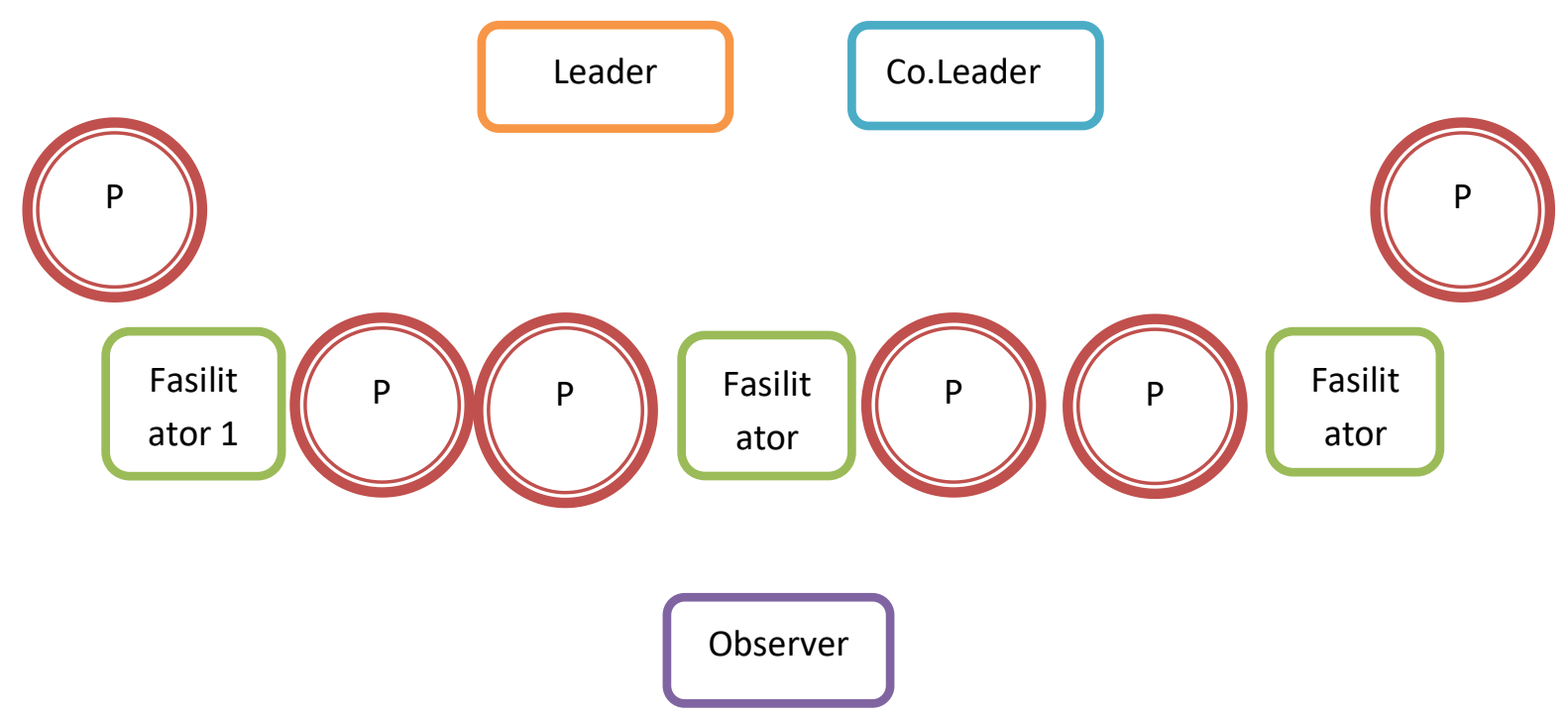

Keterangan Gambar:

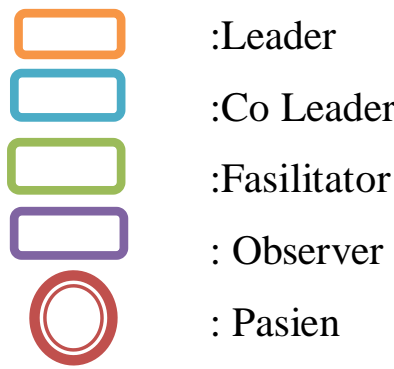

2.11 Tata tertib dan Antisipasi Masalah

1. Tata tertib pelaksanaan TAK Halusinasi ( Gg. Perseppsi Sensori)

a. Peserta bersedia mengikuti kegiatan TAK Halusinasi ( Gg. Persepsi Sensori) sampai dengan selesai

b. Peserta wajib hadir 5 menit sebelum acara TAKHalusinasi ( Gg. Persepsi Sensori) dimulai

c. Peserta berpakaian rapi, bersih, dan sudah mandi 
d. Peserta tidak diperkenankan makan, minum, merokok selama kegiatan TAK berlangsung

e. ika ingin mengajukan/menjawab pertanyaan, peserta mengangkat tangan kanan dan berbicara setelah dipersilahkan oleh pemimpin

f. Peserta yang mengacaukan jalannya acara akan dikeluarkan dari permainan

g. Peserta dilarang meninggalkan tempat sebelum acara TAK selesai

h. pabila waktu yang ditentukan untuk melaksanakan TAK telah habis, sedangkan permainan belum selesai, maka pemimpin akan meminta persetujuan anggota untuk memperpanjang waktu TAK

\section{Antisipasi kejadian yang tidak diinginkan pada proses TAK}

Penanganan Pasien yang tidak efektif saat aktifitas kelompok

a. Memanggil Pasien

b. Memberi kesempatan kepada Pasien tersebut untuk menjawab sapaan perawat atau Pasienyang lain

\section{Bila Pasien meninggalkan permainan tanpa pamit:}

a. Panggil nama Pasien

b. Tanya alasan Pasien meninggalkan permainan

c. Berikan penjelasan tentang tujuan permainan dan berikan penjelasan pada Pasien bahwaPasien dapat melaksanakan keperluannya setelah itu Pasien boleh kembali lagi

\section{Bila ada Pasien lain ingin ikut}

a. Berikan penjelasan bahwa permainan ini ditujukan pada Pasien yang telah dipilih

b. Katakan pada Pasien lain bahwa ada permainan lain yang mungkin dapat diikuti oleh Pasien tersebut

c. Jika Pasien memaksa, beri kesempatan untuk masuk dengan tidak memberi peran pada permainan tersebut 


\section{BAB 3 \\ EVALUASI}

Kegiatan TAK dilaksanakan pada 17 Maret 2021 Jam 10.00 WIB sesuai dengan rencana yang ada diproposal. Kegiatan dilakukan di Halaman Yayasan Pemenang Jiwa Sumatera, yang seharusnya dilaksanakan di dalam ruangan, dikarenakan ruangan di yayasan pemenang jiwa sumatera digunakan pihak yayasan untuk kegiatan yang lain. Pasien berjumlah 6 orang peserta, laki-laki 1 orang dan perempuan 5 orang sesuai dengan proposal yang telah diajukan. Dalam terapi aktivitas kelompok perawat melakukan kontrak kepada pasien sehari sebelum TAK dilakukan. Mempersiapkan alat dan menyeting tempat dilakukan sebelum pasien datang di tempat pelaksanaan TAK.

Sebelum TAK dilaksanakan, leader memperkenalkan diri kepada pasien dan leader memberikan kesempatan untuk co-leader, fasilitator dan observer untuk memperkenalkan diri kepada pasien dan memberikan pasien kesempatan untuk memperkenalkan dirinya masing-masing. Leader dan co-leader saling bergantian menjelaskan peraturan terapi aktivitas kelompok, seperti bagiamana peraturan yang di buat saat terapi aktivitas kelompok dilaksanakan, durasi berjalannya terapi aktivitas kelompok dan memberikan infromasi kepada pasien bahwa perawat yang berada disebelah pasien sebagai fasilitator untuk membantu pasien selama berjalannya terapi aktivitas kelompok.

Dalam terapi aktivitas kelompok, leader dan co-leader sudah melakukan tugasnya untuk menjelaskan jalannya terapi aktivitas kelompok dan memimpin jalannya terapi. Fasilitator sudah melakukan tugasnya untuk membantu pasien selama berjalannya terapi aktivitas kelompok. Observer telah melakukan tugasnya dengan mengamati jalannya terapi aktivitas kelompok apakah pasien mampu melakukan sp yang sudah ditentukan terapis. 
Respon pasien saat diberikan terapi aktivitas kelompok yaitu :

a. Kemampuan Menganal Halusinasi

Pasien mengatakan mendengar Suara saat menyandiri, suara muncul saat klien sedang sendiri.

b. Kemampuan Menghardik Halusinasi

Pasien mengatakan jika halusinasi muncul pasien berdoa dan menolak suara tersebut. Pasien memperagakan teknik meghardik.

c. Kemampuan Patuh Minum Obat

Pasien mengatakan minum obat $2 \mathrm{x} /$ hari. Pasien mengatakan keuntungan dengan minum obat yaitu suara-suara halusinasi tersebut hilang dan pasien bisa tidur dengan nyenyak.

d. Kemampuan Bercakap-cakap

Pasien mengatakan suka mengalihkan suara yang datang dengan mengobrol bersama teman satu kamarnya atau dengan teman yang didekatnya

e. Kemampuan Membuat Jadwal Kegiatan

Pasien mengatakan melakukan kegiatan terjadwal dari pagi sampai malam, sesuai dengan aktivitas yang biasa dilakukan diyayasan pemenang jiwa sumatera utara 


\section{BAB 4 \\ PENUTUP}

\subsection{Kesimpulan}

Terapi Aktivitas Kelompok (TAK) Stimulasi Persepsi adalah Pasien dilatih mempersiapkan Stimulus yang disediakan atau Stimulus yang pernah dialami. Tujuan dari Terapi Aktivitas untuk memantau dan meningkatkan Hubungan Interpersonal antaranggota. HasiL diskusi kelompok dapat berupa kesepakatan atau Alternatif Penyelesaian masalah. (Maulana,hernawati \& Syalahuddin,2021)

Salah satu bentuk penanganan medis untuk pasien dengan halusinasi adalah dengan Terapi Aktifitas Kelompok Stimulasi Persepsi, dimana TAK (Terapi Aktifitas Kelompok) merupakan salah satu terapi modalitas yang dilakukan perawat kepada kelompok pasien dengan halusinasi. Aktivitas digunakan sebagai terapi,dan kelompok digunakan sebagai target asuhan. Di dalam kelompok terjadi dinamika interaksi yang saling bergantung, saling membutuhkan, dan menjadi laboratorium tempat pasien berlatih perilaku baru yang adaptif untuk memperbaiki perilaku lama yang maladaptif (Keliat \& Akemat, 2015).

Setelah mendapatkan terapi aktivitas kelompok stimulasi persepsi sensori (halusinasi) ,pasien terapi aktivitas kelompok di yayasan pemenang jiwa sumatera utara terjadi peningkatan pengetahuan, pemahaman tentang cara mengontrol halusinasi dan tahu bagaimana cara melakukannya. Peningkatan pengetahuan diketahui bahwa pasien mampu mengingat sp 1 - 4 dari permainan terapi aktivitas kelompok. 


\subsection{Saran}

Diharapkan bagi Perawat di Yayasan Pemenang Jiwa menjadikan Terapi Aktivitas Kelompok stimulasi persepsi sebagai tindakan keperawatan untuk setiap pasien dengan masalah gangguan jiwa khususnya pasien Halusinasi karena menurut hasil penelitian (Putri, 2017) TAK Stimulasi persepsi yang diberikan pada Pasien Halusinasi memberikan pengaruh yang signifikan terhadap kemampuan mengenal dan mengontrol halusinasi baik secara fisik maupun secara social 


\section{DAFTAR PUSTAKA}

Andri, J., Febriawati, H., Panzilion, P., Sari, S. N., \& Utama, D. A. (2019). Implementasi Keperawatan Dengan Pengendalian Diri Pasien Halusinasi Pada Pasien Skizofrenia. Jurnal Kesmas Asclepius, 1(2), 146-155. https://doi.org/10.31539/jka.v1i2.922

Ariandy, W., dkk.(2018). Terapi Aktivitas Kelompok Stimulasi Persepsi Berhubungan dengan Kemampuan pasien dalam Mengontrol Halusinasi. Jurnal keperawatan aisyiyah.14 (1).83-90 http://dx.doi.org/10.26714/jkj.9.1.2021.153-160

Aritonang, M. (2021).Efektifitas Terapi Aktivitas Kelompok Stimulasi Terhadap Kemampuan mengontrol Halusinasi Pendengaran Pada Pasien Ruangan cempaka di RSJ Prof. Dr. M. Ildrim Medan Tahun 2019.Jurkes Sutra: Jurnal kesehatan Surya Nusantara, 9 (1)

Maulana, I., Hernawaty, T., \&Shalahuddin, I. (2021).Terapi Aktivitas Kelompok menurunkan Tingkat Halusinasi pada Pasien Skizofrenia: Literature Review. Jurnal Keperawatan Jiwa (JKJ): Persatuan Perawat Nasional Indonesia, 9(1), 153-160.

Nasriati, R. (2017). Stigma dan dukungan keluarga dalam merawat orang dengan gangguan jiwa (ODGJ). MEDISAINS, 15(1), 56-65. http://dx.doi.org/10.30595/medisains.v15i1.1628

Pardede, J. A. (2020). Beban Keluarga Berhubungan Dengan Koping Saat Merawat Pasien Halusinasi.Jurnal Ilmu Keperawatan Jiwa 3(4), 445452,https://doi.org/10.37287/jppp.v2i4.183

Pardede, J. A, \& Hasibuan, E. K, (2019). Dukungan Caregiver Dengan Frekuensi Kekambuhan Pasien Skizofrenia. Idea Nursing Journal, 10(2)

Pardede, J. A., \& Laia, B. (2020). Decreasing Symptoms of Risk of Violent Behavior in Schizophrenia Patients Through Group Activity Therapy. Jurnal Ilmu Keperawatan Jiwa, 3(3), 291-300. http://dx.doi.org/10.32584/jikj.v3i3.621

Pardede, J. A., \& Ramadia, A. (2021). The Ability to Interact With Schizophrenic Patients through Socialization Group Activity Therapy. International Journal of Health Science and Medical Research, 1(1), 06-10.

Pardede, J. A (2020). Decreasing Hallucination Response Through Perception Stimulation Group Activity Therapy In Schizophrenia Patients. Iar Journal of Medical Sciences. 1(6), 304-309. 
Putri, V. (2017).Pengaruh terapi aktivitas kelompok stimulasi persepsi halusinasi terhadap kemampuan mengontrol halusinasi pada pasien skizofrenia di ruang rawat inap Arjuna Rumah Sakit Jiwa Daerah Provinsi Jambi. Riset Informasi Kesehatan, 6(2), 174-183. doi:10.30644/rik.v6i2.95

Samal, M., Ahmad, A., \&Saidah, S. (2018). Pengaruh Penerapan Asuhan Keperawatan Pada Pasien Halusinasi Terhadap Kemampuan Pasien Mengontrol Halusinasi Di Rskd Provinsi Sulawesi Selatan. JurnalImiahKesehatan Diagnosis, 12(5), 546-550.

Rohmani, R., Lestari, N. L. N., \&Kismiyati, K. (2020).Pengaruh Terapi Aktivitas Kelompok Terhadap Kemampuan Komunikasi Verbal Pasien Halusinasi Di Rumah Sakit Jiwa Abepura. Jurnal KeperawatanTropis Papua, 3(1), 151156.https://doi.org/10.47539/jktp.v3i1.105 
